\title{
TINGKAT KEPEDULIAN MASYARAKAT TERHADAP PENGELOLAAN SAMPAH RUMAH TANGGA DI KOTA BANDA ACEH
}

\author{
(Level of Community Awareness of Household Waste Management in Banda Aceh City)
}

\author{
Teuku M. Hafizh ${ }^{1}$, Azhar $^{1}$, Ahmad Humam Hamid ${ }^{1 *}$ \\ ${ }^{1}$ Program Studi Agribisnis, Fakultas Pertanian, Universitas Syiah Kuala
}

\begin{abstract}
Abstrak. Pengelolaan Sampah Rumah Tangga dan Sampah Sejenis Sampah Rumah Tangga telah diundangkan pada tanggal 15 Oktober 2012. Peraturan pemerintah ini sangat penting sebagai peraturan pelaksana UU Nomor 18 Tahun 2008 tentang Pengelolaan Sampah, sekaligus memperkuat landasan hukum bagi penyelenggaraan pengelolaan sampah di Indonesia, khususnya di daerah. Penelitian ini bertujuan untuk melihat sebesapa besar tingkat kepedulian masyarakat terhadap pengelolaan sampah rumah tangga di kota Banda Aceh dan melihat hubungan antara variabel bebas (X) yaitu pengetahuan, persepsi dan sikap dengan variabel terikat $(\mathrm{Y})$ pengelolaan sampah rumah tangga. Tingkat pengetahuan masyarakat terhadap pengelolaan sampah rumah tangga didapat sebanyak $76 \%$ masyarakat berpengetahuan baik, tingkat persepsi masyarakat terhadap pengelolaan sampah rumah tangga didapat sebanyak 54\% masyarakat berpersepsi baik, dan tingkat sikap masyarakat terhadap pengelolaan sampah rumah tangga didapat sebanyak 53\% masyarakat bersikap baik. Hasil analisis korelasi Rank Spearman terdapat hubungan signifikan yang cukup dan berhubungan searah antara variabel pengetahuan dengan pengelolaan sampah rumah tangga, hubungan persepsi dengan pengelolaan sampah rumah tangga di Kota Banda Aceh adalah tidak terdapat hubungan yang signifikan dan tidak searah antara variabel persepsi dengan pengelolaan sampah rumah tangga, dan hubungan sikap dengan pengelolaan sampah rumah tangga di Kota Banda Aceh adalah tidak terdapat hubungan yang signifikan dan tidak searah antara variabel sikap dengan pengelolaan sampah rumah tangga.
\end{abstract}

Kata kunci : Kepedulian masyarakat, pengetahuan, persepsi, sikap,pengelolaan sampah rumah tangga

Abstract. Household Waste Management and other kind of Household Waste has been enacted on October 15, 2012. This government regulation is very important as the implementing regulation of Law No. 18 of 2008 on Waste Management, as well as strengthening the legal basis for waste management in Indonesia, especially in the regions. This research is intended to see how big the level of public awareness of household waste management in Banda Aceh city and to see the relation between independent variable $(\mathrm{X})$ that is knowledge, perception and attitude with dependent variable (Y) household waste management. The level of public knowledge about household waste management is $76 \%$ of the people with good knowledge, the level of public perception on household waste management is $54 \%$ of people with good perception, and the community level on the household waste management is $53 \%$ of people with good attitude. The result of Rank Spearman rank analysis has significant correlation and has enough correlation between knowledge variable with household waste management, perception correlation with household waste management in Banda Aceh city there is no significant correlation and unidirectional between perception variable with household waste management, and correlation attitude with the household waste management in Banda Aceh City there is no significant correlation and unidirectional between attitude variable with household waste management.

Keywords: Community awareness, knowledge, perception, attitude, household waste management

\section{PENDAHULUAN}

Masalah sampah dihadapi hampir seluruh negara di dunia. Menurut Kementrian Lingkunan Hidup dan Kehutanan, jumlah sampah padat dikota-kota dunia akan terus meningkat setiap tahunnya sebesar 70\%, hingga tahun 2025 dari 1,3 miliar ton pertahun menjadi 2,2 miliar ton pertahun, mayoritas terjadi di kota-kota di negara berkembang. Berdasarkan data Kementerian Lingkungan Hidup dan Kehutanan, Indonesia sendiri menghadapi permasalahan 
sampah yang merupakan masalah rumit karena kurangnya pengetahuan terhadap akibat-akibat yang dapat ditimbulkan oleh sampah. Setiap hari rata-rata setiap orang di Indonesia menghasilkan $2 \mathrm{Kg}$ sampah.

Sampah kota diartikan sebagai sampah-sampah organik maupun non organik yang dibuang oleh masyarakat dari berbagai lokasi di kota tersebut (Simanjuntak dan Sariguna, 2007). Sampah dari perumahan adalah penyumbang terbesar dari sampah perkotaan. Mengelola sampah mulai dari rumah atau lingkungan masing-masing saat ini seharusnya sudah menjadi gaya hidup masyarakat.

Kementerian Lingkungan Hidup, pada tanggal 1 November 2012 di Jakarta menyampaikan substansi penting dari Peraturan Pemerintah Nomor 81 Tahun 2012 tentang Pengelolaan Sampah Rumah Tangga dan Sampah Sejenis Sampah Rumah Tangga yang telah diundangkan pada tanggal 15 Oktober 2012. Peraturan pemerintah ini sangat penting sebagai peraturan pelaksana UU Nomor 18 Tahun 2008 tentang Pengelolaan Sampah, sekaligus memperkuat landasan hukum bagi penyelenggaraan pengelolaan sampah di Indonesia, khususnya di daerah.

Menteri Negara Lingkungan Hidup, Prof. DR. Balthasar Kambuaya, MBA, pada tahun 2013 menyatakan, bahwa PP No. 81 Tahun 2012 akan mewujudkan pengelolaan sampah yang berwawasan lingkungan yang bertumpu pada penerapan $3 \mathrm{M}$ dalam rangka penghematan sumber daya alam, penghematan energi, pengembangan energi alternatif dari pengolahan sampah, perlindungan lingkungan, dan pengendalian pencemaran di rumah tangga.

Dinas DLHDK3 Kota Banda Aceh pada tahun 2016 juga menyatakan bahwa karakteristik sampah di Kota Banda Aceh tidak jauh berbeda dengan kota-kota lainnya di Indonesia, dimana bahan organik merupakan komponen utama yang mencapai 52\% (misalkan untuk sampah rumah tangga), sedangkan kertas/kardus dan sampah plastik menempati urutan kedua dan ketiga yang masing-masing memiliki komposisi sebesar 16\% dan 14\%. Sampah rumah tangga menjadi sumber timbunan sampah terbesar di Kota Banda Aceh dengan persentase sebesar 52\% dari total keseluruhan timbunan sampah di Kota Banda Aceh.

Salah satu upaya yang dapat dilakukan untuk mengurangi jumlah sampah rumah tangga adalah dengan membantu dan memberikan penjelasan serta wawasan kepada masyarakat mengenai pentingnya kepedulian terhadap pengelolaan sampah rumah tangga karena sampah rumah tangga merupakan salah satu komponen sampah utama yang ada di kota Banda Aceh, dan tujuan dari penelitian ini adalah untuk mengetahui tingkat pengetahuan, persepsi dan sikap masyarakat terhadap pengelolaan sampah rumah tangga di Kota Banda Aceh dan untuk mengetahui hubungan antara pengetahuan, persepsi dan sikap dengan pengelolaan sampah rumah tangga di Kota Banda Aceh

\section{METODE PENELITIAN}

Penelitian ini dilaksanakan di Gampong Geuceu Iniem, Kota Banda Aceh. Pengambilan sampel pada setiap kepala keluarga menggunakan teknik proportional simple random sampling. Penelitian ini menggunakan Skala Guttman untuk mengukur skor variabel pengetahuan dengan tujuan mendapatkan jawaban yang tegas terhadap suatu permasalahan yang ditanyakan dan menggunakan skala Likert untuk menguur skor variabel persepsi dan sikap yang dikategorikan menjadi tiga kategori besar yaitu kurang, sedang dan baik.

Jumlah sampel dalam penelitian ini adalah responden yang tinggal menetap di Gampong Geueu Iniem yang telah ditentukan dengan menggunakan rumus Slovin dengan batas toleransi kesalahan sebesar $10 \%$ dan didapat 85 sampel.

Penelitian ini dilaksanakan di Gampong Geuceu Iniem, Kota Banda Aceh. Pengambilan sampel pada setiap kepala keluarga menggunakan teknik proportional simple random 
sampling. Penelitian ini menggunakan Skala Guttman untuk mengukur skor variabel pengetahuan dengan tujuan mendapatkan jawaban yang tegas terhadap suatu permasalahan yang ditanyakan dan menggunakan skala Likert untuk menguur skor variabel persepsi dan sikap yang dikategorikan menjadi tiga kategori besar yaitu kurang, sedang dan baik.

\section{Prosedur Pengujian Data}

Penelitian ini menggunakan Skala Guttman untuk mengukur skor variabel pengetahuan dengan tujuan mendapatkan jawaban yang tegas antara benar atau salah terhadap suatu permasalahan yang ditanyakan (Iskani, 2017) dan menggunakan skala Likert untuk mengukur skor variabel persepsi dan sikap yang dikategorikan menjadi tiga kategori besar yaitu kurang, sedang dan baik (Sudjana, 2005). Hasil dari data yang di dapat kemudian diuji validitas dan reabilitasnya menggunakan aplikasi SPSS 16.0.

\section{Analisa Statistik}

Analisa statistik yang digunakan adalah analisis Rank Spearman, yaitu dengan menyajikannya dalam bentuk tabel. untuk mencari keeratan hubungan antara dua variabel yaitu pengetahuan, persepsi dan sikap dengan pengelolaan sampah rumah tangga. Dalam menentukan tingkat kekuatan hubungan antar variabel, kita dapat berpedoman pada nilai koefisien korelasi yang merupakan hasil dari output SPSS 16.0.

\section{HASIL DAN PEMBAHASAN}

\section{Pengetahuan Masyarakat Terhadap Pengelolaan Sampah Rumah Tangga}

Pengetahuan pengelolaan sampah rumah tangga merupakan pemahaman paling dasar yang sangat penting untuk dipahami oleh masyarakat rumah tangga itu sendiri. Dengan demikian, diharapkan masyarakat rumah tangga mampu memahami pentingnya pengelolaan sampah rumah tangga bagi mereka.

Pengetahuan atau kognitif merupakan domain yang sangat penting dalam membentuk tindakan seseorang (Notoatmodjo, 2007).

Distribusi pengetahuan masyarakat (responden) sebanyak 85 orang terhadap pengelolaan sampah rumah tangga disajikan dalam Tabel 1

Tabel 1. Distribusi Pengetahuan Masyarakat terhadap Pengelolaan Sampah Rumah Tangga

\begin{tabular}{ccc}
\hline Item Pertanyaan & Jawaban Benar & Jawaban Salah \\
\hline P1 & 35 & 50 \\
P2 & 57 & 28 \\
P3 & 39 & 46 \\
P4 & 81 & 4 \\
P5 & 70 & 15 \\
P6 & 72 & 13 \\
P7 & 65 & 20 \\
P8 & 74 & 11 \\
P9 & 78 & 7 \\
P10 & 81 & 4 \\
Total & 652 & 198 \\
Rata-rata & 65 & 20 \\
\hline
\end{tabular}

Sumber: Data Primer (Diolah), 2017

$\mathrm{P}=$ Pertanyaan 
Untuk mengetahui posisi persentase jawaban benar yang diperoleh dari kuisioner maka dihitung terlebih dahulu kemudian ditempatkan dalam rentang skala persentase sebagai berikut:

Skor Jawaban Benar

Skor Jawaban Salah

Dikonversikan menjadi persentase

Jawaban Benar

Jawaban Salah

\section{Perhitungan Jawaban Benar dari kuisioner}

$: 1$

$: 0$

Jawaban benar rata-rata

Jawaban salah rata-rata
$: 100 \%$
$: 0 \%$ (tidak perlu dihitung)

: $65 / 85 \times 100 \%=76 \%(0,76)$

$: 20 / 85 \times 100 \%=24 \%(0,24)$

Sehingga bila digambarkan dalam skala:

$0 \%$ $-24 \%$ $-50 \%$ $-76 \%$ $-100 \%$

Gambar 1. Skala Interpretasi Skor Pengetahuan

Dari hasil analisis Skala Guttman, hasil yang diperoleh adalah $76 \%$ responden atau 0,76 , sesuai tabel interpretasi terletak pada rentang 0,51 - 0,99 dan terdapat $24 \%$ responden atau 0,24, sesuai tabel interpretasi terletak pada rentang 0,01 - 0,49. Sehingga dapat dikatakan sebanyak $76 \%$ responden, pengetahuan terhadap pengelolaan sampah rumah tangga dalam kategori baik dan sebanyak $24 \%$ responden, pengetahuan terhadap pengelolaan sampah rumah tangga dalam kategori kurang.

Maka pengetahuan masyarakat terhadap pengelolaan sampah rumah tangga di Kota Banda Aceh dapat disimpulkan sebanyak 65 responden baik, dengan persentase sebesar $76 \%$ dari total 85 responden.

\section{Persepsi Masyarakat Terhadap Pengelolaan Sampah Rumah Tangga}

Proses pembentukan persepsi dimulai dengan penerimaan rangsangan dari berbagai sumber melalui panca indera yang dimiliki, setelah itu diberikan respon sesuai dengan penilaian dan pemberian arti terhadap rangsang lain. Setelah diterima rangsangan atau data yang ada diseleksi (Ramadhan, 2009).

Walgito Bimo pada tahun 2004, mengungkapkan bahwa persepsi merupakan suatu proses pengorganisasian, penginterpretasian terhadap stimulus yang diterima oleh organisme atau individu sehingga menjadi sesuatu yang berarti,dan merupakan aktivitas yang terintegrasi dalam diri individu.. Sejalan dengan pernyataan Azwar (2010), persepsi yang benar terhadap suatu objek sangat diperlukan karena persepsi merupakan dasar dari pembentukan suatu sikap.

Distribusi persepsi masyarakat (responden) sebanyak 85 orang terhadap pengelolaan sampah rumah tangga disajikan dalam Tabel 2 dan Gambar 2

Tabel 2. Distribusi Persepsi Masyarakat terhadap Pengelolaan Sampah Rumah Tangga

\begin{tabular}{lcc}
\hline No & Kategori & Jumlah (Orang) \\
\hline 1 & Kurang (Skor 12-14) & 3 \\
2 & Sedang (Skor 15-17) & 36 \\
3 & Baik (Skor 18) & 46 \\
\hline
\end{tabular}

Sumber: Data Primer (diolah), 2017 


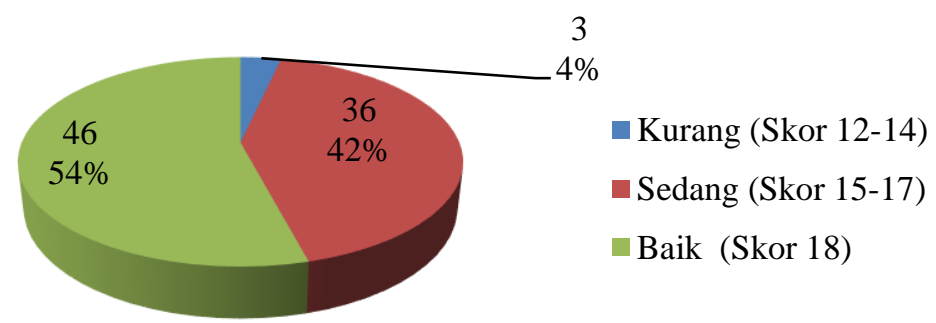

Gambar 2. Skor dan Persentase Persepsi Masyarakat terhadap Pengelolaan Sampah Rumah Tangga

Pada Tabel 2 dan Gambar 2 dapat dilihat bahwa untuk masyarakat rumah tangga yang memiliki persepsi dalam kategori baik terhadap pengelolaan sampah rumah tangga berjumlah 46 orang atau sekitar $54 \%$. Dengan demikian dapat dikatakan bahwa mereka memiliki penilaian yang baik bahkan sangat baik terhadap pengelolaan sampah rumah tangga. Berdasarkan hasil penelitian, sebagian besar masyarakat rumah tangga yang memiliki persepsi dalam kategori tinggi cenderung didominasi oleh masyarakat yang memiliki rangsangan yang baik dari lingkungan rumah tangga, proses belajar yang baik sehingga mampu memberikan tanggapan yang baik serta memiliki pengalaman baik dalam mengelola sampah rumah tangga.

Selanjutnya terdapat 36 orang masyarakat rumah tangga atau sekitar $42 \%$ yang memiliki persepsi dalam kategori sedang terhadap pengelolaan sampah rumah tangga. Masyarakat yang memiliki persepsi dalam kategori sedang tersebut cenderung memberikan pendapat yang baik namun cenderung terdapat pendapat yang netral pada pernyataan yang diberikan. Artinya mereka lebih memberikan respon cukup baik sesuai proses belajar dan pengalaman dari keadaan lingkungan sehingga dapat memberikan tanggapan yang cukup baik terhadap pengelolaan sampah rumah tangga tersebut.

juga dapat dilihat bahwa sangat sedikit bahkan cenderung tidak ada masyarakat rumah tangga yang menjadi responden memiliki persepsi dalam kategori kurang terhadap pengelolaan sampah rumah tangga. Masyarakat yang memilki persepsi dalam kategori kurang berjumlah 3 orang atau sekitar hanya $4 \%$ dari total jumlah responden. Kurangnya persepsi bagi sebagian masyarakat tersebut disebabkan karena masyarakat memiliki pendapat yang berbeda mengenai rangsangan di lingkungan sekitar rumahnya, proses belajar untuk memahami yang berbeda serta pengalaman yang didapat dari lingkungan rumahnya mengenai bagaimana pengelolaan sampah yang baik di rumah tangga.

\section{Sikap Masyarakat terhadap Pengelolaan Sampah Rumah Tangga}

Sikap secara nyata menunjukkan konotasi adanya kesesuaian reaksi terhadap stimulus tertentu yang dalam kehidupan sehari-hari merupakan reaksi yang bersifat emosional terhadap stimulus sosial, dalam hal ini dalam menyikapi mengenai pengelolaan sampah rumah tangga (Notoatmodjo, 2007)

Distribusi persepsi masyarakat (responden) sebanyak 85 orang terhadap pengelolaan sampah rumah tangga disajikan dalam Tabel 3 dan Gambar 3

Tabel 3. Distribusi Sikap Masyarakat terhadap Pengelolaan Sampah Rumah Tangga

\begin{tabular}{lcc}
\hline No & Kategori & Jumlah (Orang) \\
\hline 1 & Kurang (Skor 8-10) & 2 \\
2 & Sedang (Skor 11-13) & 38 \\
3 & Baik (Skor 14) & 45 \\
\hline
\end{tabular}

Sumber: Data Primer (diolah), 2017 


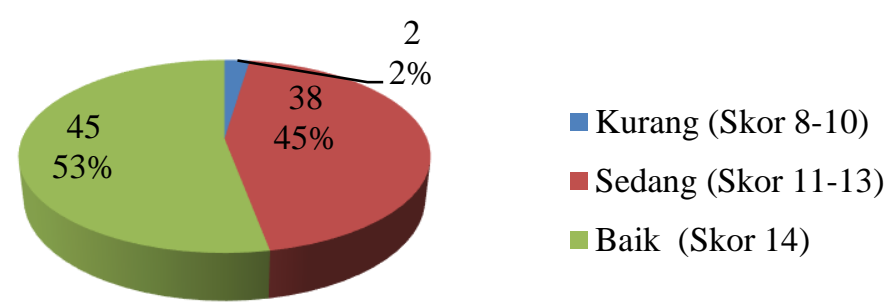

Gambar 3. Skor dan Persentase Sikap Masyarakat terhadap Pengelolaan Sampah Rumah Tangga

Pada Tabel 3 dan Gambar 3 dapat dilihat bahwa untuk masyarakat rumah tangga yang memiliki sikap dalam kategori baik terhadap pengelolaan sampah rumah tangga berjumlah 45 orang atau sekitar 53\%. Dengan demikian dapat dikatakan bahwa mereka memiliki penilaian yang baik bahkan sangat baik dalam menyikapi terhadap pengelolaan sampah rumah tangga. Berdasarkan hasil penelitian, sebagian besar masyarakat rumah tangga yang memiliki sikap dalam kategori tinggi cenderung didominasi oleh masyarakat yang memiliki stimulus yang baik dalam pengelolaan sampah, dapat merespon dengan baik pernyataan mengenai pengelolaan yang dapat dilakukannya, setuju untuk menghargai sesama dengan mengajak berdiskusi mengenai pengelolaan sampah yang baik dalam melaksanakan pengelolan sampah di rumah tangga.

Selanjutnya terdapat 38 orang masyarakat rumah tangga atau sekitar $45 \%$ yang memiliki sikap dalam kategori sedang terhadap pengelolaan sampah rumah tangga. Masyarakat yang memiliki persepsi dalam kategori sedang tersebut cenderung memberikan pendapat yang baik dalam menyikapi namun terdapat pendapat yang netral pada pernyataan yang diberikan. Artinya mereka lebih memberikan respon cukup baik dari penilaian sikap masyarakat terhadap pengelolaan sampah rumah tangga tersebut. Hal ini disebabkan karena menurut pendapat mereka sudah cukup dalam memperhatikan stimulus terhadap pengelolaan sampah rumah tangga, sehingga mereka belum tanggapan maksimal dalam pengelolaan sampah rumah tangga.

Masyarakat yang memilki persepsi dalam kategori kurang hanya berjumlah 2 orang atau sekitar hanya $2 \%$ dari total jumlah responden. Rendahnya sikap bagi sebagian masyarakat tersebut disebabkan karena masyarakat memberikan sikap mengenai pengelolaan sampah dirumah tangga dengan caranya sendiri, tidak memperhatikan stimulus dalam pengelolaan sampah rumah tangga, tidak memberikan respon yang baik ketika menanggapi, memilih untuk tidak menghargai terhadap masyarakat mengenai pengelolaan sampah di lingkungannya sesuai dengan pengelolaan sampah yang baik dan benar di rumah tangga.

\section{Pengelolaan Sampah Rumah Tangga}

Pada tahun 2011 Yolarita menyatakan bahwa paradigma baru dalam pengelolaan sampah lebih menekankan pada pengurangan sampah dari sumber untuk mengurangi jumlah timbulan sampah serta mengurangi dampak negatif yang ditimbulkan dari sampah. Maka dari itu, prinsip 3M (Mengurangi, Menggunakan kembali, Mendaur ulang) sejalan dengan pengelolaan sampah yang menitikberatkan pada pengurangan sampah dari sumbernya.

Pengelolaan sampah rumah tangga yang diukur dalam penelitian ini adalah seberapa baik masyarakat rumah tangga dalam melakukan pengelolaan sampah rumah tangga. Pengamatan tersebut sangat perlu dilakukan untuk mengetahui apakah pengetahuan, persepsi dan sikap berhubungan positif atau negatif terhadap pengelolaan sampah rumah tangga di Kota Banda Aceh. 
Distribusi pengelolaan sampah rumah tangga disajikan dalam Tabel 4 dan Gambar 4

Tabel 4. Distribusi Pengelolaan Sampah Rumah Tangga

\begin{tabular}{lcc}
\hline No & Kategori & Jumlah (Orang) \\
\hline 1 & Kurang (Skor 1-2) & 33 \\
2 & Sedang (Skor 3-4) & 44 \\
3 & Baik (Skor 5-6) & 8 \\
\hline
\end{tabular}

Sumber: Data Primer (diolah), 2017

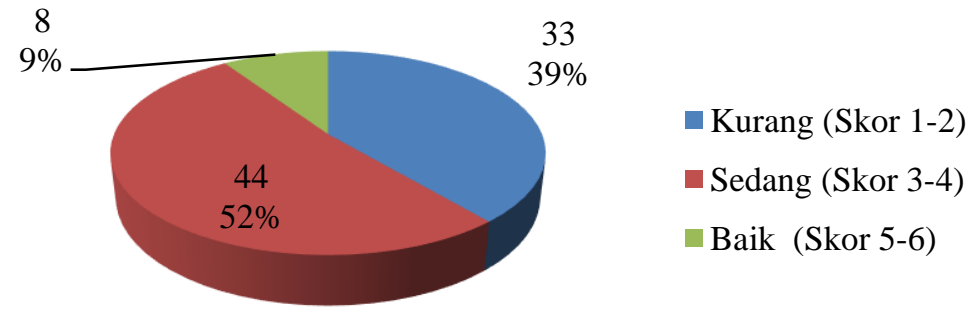

Gambar 4. Skor dan Persentase Pengelolaan Sampah Rumah Tangga

Berdasarkan Tabel 4 dan Gambar 4 dapat dilihat bahwa 39\% atau 33 responden masyarakat rumah tangga memiliki skor kurang dalam melakukan pengelolaan sampah rumah tangga. Skor kurang tersebut diakibatkan masyarakat melakukan pengelolaan sampah rumah tangga hanya seadanya, jarang melakukan pengelolaan sampah yang baik berdasarkan $3 \mathrm{M}$ dan hanya mengandalkan pembayaran retribusi untuk nantinya sampah rumah tangga mereka di angkut ke TPA. Kemudian juga banyak masyarakat yang memilih untuk membakar sampah rumah tangga mereka diakibatkan truk pengangkut sampah tidak mau mengangkut sampah daun-daun kering masyarakat, dan ini juga menjadi keluhan masyarakat yang menyebabkan mereka memilih untuk membakar sampah rumah tangganya. Ini yang menjadi dasar mengapa $39 \%$ masyarakat memiliki skor yang kurang dalam mengelola sampah rumah tangganya.

\section{Hubungan Pengetahuan dengan Pengelolaan Sampah Rumah Tangga}

Untuk mengetahui hubungan antara pengetahuan dengan pengelolaan sampah rumah tangga dilakukan dengan menggunakan uji korelasi Rank Spearman's dengan bantuan perangkat SPSS (Statistical Package for Social Sciences). Hasil perhitungan yang telah dilakukan disajikan dalam Tabel 5 berikut:

Tabel 5. Hasil Output Analisis Korelasi Rank Spearman's Hubungan Pengetahuan dengan Pengelolaan Sampah Rumah Tangga 


\begin{tabular}{|c|c|c|c|c|}
\hline \multicolumn{5}{|c|}{ Korelasi } \\
\hline & & & Skor Pengetahuan & $\begin{array}{c}\text { Skor } \\
\text { Pengelolaan } \\
\text { Sampah } \\
\text { Rumah Tangga }\end{array}$ \\
\hline \multirow[t]{6}{*}{ Spearman's rho } & \multirow[t]{3}{*}{ Skor Pengetahuan } & Koefisien Korelasi & 1.000 & $.372^{* *}$ \\
\hline & & Sig. (2-tailed) & . & .000 \\
\hline & & $\mathrm{N}$ & 85 & 85 \\
\hline & \multirow{3}{*}{$\begin{array}{l}\text { Skor Pengelolaan Sampah } \\
\text { Rumah Tangga }\end{array}$} & Koefisien Korelasi & $.372^{* *}$ & 1.000 \\
\hline & & Sig. (2-tailed) & .000 & \\
\hline & & $\mathrm{N}$ & 85 & 85 \\
\hline
\end{tabular}

Tingkat kekuatan (keeratan) hubungan variabel pengetahuan dengan pengelolaan sampah rumah tangga berdasarkan output di atas, maka diperoleh angka koefisien korelasi sebesar $0,372 * *$. Artinya, tingkat kekuatan hubungan (korelasi) antara variabel pengetahuan dengan pengelolaan sampah rumah tangga adalah sebesar 0,372 atau dinyatakan hubungan cukup. Tanda bintang (**) artinya korelasi bernilai signifikan sebesar 0,01 .

Melihat arah (jenis) hubungan variabel pengetahuan dengan pengelolaan sampah rumah tangga, angka koefisien korelasi pada hasil diatas bernilai positif, yaitu 0,372, sehingga hubungan kedua variabel tersebut bersifat searah (jenis hubungan searah), dengan demikian dapat diartikan bahwa pengetahuan masyarakat semakin ditingkatkan maka pengelolaan sampah rumah tangga juga akan meningkat.

Melihat signifikansi hubungan kedua variabel berasarkan output di atas, diketahui nilai signifikansi atau sig. (2-tailed) sebesar 0,000, karena nilai sig. (2-tailed) 0,000 < lebih kecil dari 0,05 atau 0,01 maka artinya ada hubungan yang signifikan (berarti) antara variabel pengetahuan dengan pengelolaan sampah rumah tangga.

Hal tersebut dikarenakan hasil skoring yang tidak berbeda jauh antara pengetahuan masyarakat yang sebesar $24 \%$ berpengetahuan dengan skor kurang dengan pengelolaan sampah rumah tangga di masyarakat yang 39\% melakukan pengelolaan sampah rumah tangga dengan skor kurang. Masyarakat bisa meningkatkan pengetahuannya lebih baik diikuti dengan pengelolaan sampah yang akan meningkat sesuai dengan pengetahuan yang dimiliki oleh masyarakat, dikarenakan tingkatan dari pengetahuan mengenai aplikasi masyarakat dalam pengelolaan sampah, yang mana masyarakat memiliki kemampuan untuk menggunakan pemahamannya yang sudah dimilikinya untuk diaplikasikan langsung pengelolaan sampah rumah tangganya.

\section{Hubungan Persepsi dengan Pengelolaan Sampah Rumah Tangga}

Untuk mengetahui hubungan antara persepsi dengan pengelolaan sampah rumah tangga dilakukan dengan menggunakan uji korelasi Rank Spearman's dengan bantuan perangkat SPSS (Statistical Package for Social Sciences). Hasil perhitungan yang telah dilakukan disajikan dalam Tabel 6 berikut:

Tabel 6. Hasil Output Analisis Korelasi Rank Spearman's Hubungan Persepsi dengan Pengelolaan Sampah Rumah Tangga 


\begin{tabular}{|c|c|c|c|c|}
\hline \multicolumn{5}{|c|}{ Korelasi } \\
\hline & & & SkorPersepsi & $\begin{array}{c}\text { Skor } \\
\text { Pengelolaan } \\
\text { Sampah } \\
\text { Rumah Tangga }\end{array}$ \\
\hline \multirow[t]{6}{*}{ Spearman's rho } & \multirow[t]{3}{*}{ Skor Persepsi } & Koefisien Korelasi & 1.000 & -.026 \\
\hline & & Sig. (2-tailed) & . & .817 \\
\hline & & $\mathrm{N}$ & 85 & 85 \\
\hline & \multirow{3}{*}{$\begin{array}{l}\text { Skor Pengelolaan Sampah } \\
\text { Rumah Tangga }\end{array}$} & Koefisien Korelasi & -.026 & 1.000 \\
\hline & & Sig. (2-tailed) & .817 & \\
\hline & & $\overline{\mathrm{N}}$ & 85 & 85 \\
\hline
\end{tabular}

Tingkat kekuatan (keeratan) hubungan variabel persepsi dengan pengelolaan sampah rumah tangga berdasarkan output di atas, maka diperoleh angka koefisien korelasi sebesar 0,026. Artinya, tingkat kekuatan hubungan (korelasi) antara variabel persepsi dengan pengelolaan sampah rumah tangga adalah sebesar -0,026 atau dinyatakan hubungan sangat lemah.

Melihat arah (jenis) hubungan variabel persepsi dengan pengelolaan sampah rumah tangga, angka koefisien korelasi pada hasil diatas bernilai negatif, yaitu -0,026, sehingga hubungan kedua variabel tersebut bersifat tidak searah (jenis hubungan tidak searah), dengan demikian dapat diartikan bahwa apabila persepsi masyarakat semakin ditingkatkan maka pengelolaan sampah rumah tangga tetap tidak akan meningkat.

Melihat signifikansi hubungan kedua variabel berasarkan output di atas, diketahui nilai signifikansi atau sig. (2-tailed) sebesar 0,817, karena nilai sig. (2-tailed) 0,817 > lebih besar dari 0,05 atau 0,01 maka artinya tidak ada hubungan yang signifikan (berarti) antara variabel persepsi dengan pengelolaan sampah rumah tangga.

Hal tersebut dikarenakan hasil scoring yang berbeda sangat jauh antara persepsi masyarakat yang sebesar 3\% berpersepsi dengan skor kurang dengan pengelolaan sampah rumah tangga di masyarakat yang sebanyak 39\% melakukan pengelolaan sampah rumah tangga dengan skor kurang. Masyarakat dapat memberikan pendapat dengan baik hanya dengan rangsangan dari lingkungan sekitar kemudian, dapat menginterpretasikan pengelolaan sampah dengan baik dan memiliki pengalaman mengenai pengelolaan sampah yang baik dan benar, dan juga keadaan lingkungan sekitar rumah tangga yang membuat masyarakat memberi tanggapan yang baik sesuai keadaan di lingkungan rumah tangganya. Mayarakat bisa berpersepsi dengan baik namun untuk tindakan yang dilakukan dalam pengelolaan sampah yang dilakukannya tidak bisa diukur dari tingkat persepsinya dikarenakan masyarakat hanya memberi tanggapan tanpa diikuti dengan aplikasi terhadap pengelolaan sampah yang baik dan benar.

\section{Hubungan Sikap dengan Pengelolaan Sampah Rumah Tangga}

Untuk mengetahui hubungan antara sikap dengan pengelolaan sampah rumah tangga dilakukan dengan menggunakan uji korelasi Rank Spearman's dengan bantuan perangkat SPSS (Statistical Package for Social Sciences). Hasil perhitungan yang telah dilakukan disajikan dalam Tabel 7 berikut:

Tabel 7. Hasil Output Analisis Korelasi Rank Spearman's Hubungan Sikap dengan Pengelolaan Sampah Rumah Tangga 


\begin{tabular}{|c|c|c|c|c|}
\hline \multicolumn{5}{|c|}{ Korelasi } \\
\hline & & & Skor Sikap & $\begin{array}{c}\text { Skor } \\
\text { Pengelolaan } \\
\text { Sampah } \\
\text { Rumah Tangga }\end{array}$ \\
\hline \multirow[t]{6}{*}{ Spearman's rho } & \multirow[t]{3}{*}{ Skor Sikap } & Koefisien Korelasi & 1.000 & -.106 \\
\hline & & Sig. (2-tailed) & . & .334 \\
\hline & & $\mathrm{N}$ & 85 & 85 \\
\hline & \multirow{3}{*}{$\begin{array}{l}\text { Skor Pengelolaan Sampah } \\
\text { Rumah Tangga }\end{array}$} & Koefisien Korelasi & -.106 & 1.000 \\
\hline & & Sig. (2-tailed) & .334 & \\
\hline & & $\mathrm{N}$ & 85 & 85 \\
\hline
\end{tabular}

Tingkat kekuatan (keeratan) hubungan variabel sikap dengan pengelolaan sampah rumah tangga berdasarkan output di atas, maka diperoleh angka koefisien korelasi sebesar 0,106 . Artinya, tingkat kekuatan hubungan (korelasi) antara variabel sikap dengan pengelolaan sampah rumah tangga adalah sebesar -0,106 atau dinyatakan hubungan sangat lemah.

Melihat arah (jenis) hubungan variabel sikap dengan pengelolaan sampah rumah tangga, angka koefisien korelasi pada hasil diatas bernilai negatif, yaitu $-0,106$, sehingga hubungan kedua variabel tersebut bersifat tidak searah (jenis hubungan tidak searah), dengan demikian dapat diartikan bahwa apabila sikap masyarakat semakin ditingkatkan maka pengelolaan sampah rumah tangga tetap tidak akan meningkat.

Melihat signifikansi hubungan kedua variabel berasarkan output di atas, diketahui nilai signifikansi atau sig. (2-tailed) sebesar 0,334, karena nilai sig. (2-tailed) 0,334 > lebih besar dari 0,05 atau 0,01 maka artinya tidak ada hubungan yang signifikan (berarti) antara variabel persepsi dengan pengelolaan sampah rumah tangga.

Hal tersebut juga dikarenakan hasil scoring yang berbeda sangat jauh antara sikap masyarakat yang sebesar $2 \%$ memberikan sikap dengan skor kurang dengan pengelolaan sampah rumah tangga di masyarakat yang mencapai 39\% melakukan pengelolaan sampah rumah tangga dengan skor kurang. Masyarakat bisa berpendapat mengenai sikapnya dengan baik hanya sesuai dengan stimulus dari pengelolaan sampah rumah tangga, dapat memberikan respon yang baik ketika menanggapi, dapat menghargai dan mendiskusikan dengan masyarakat mengenai pengelolaan sampah di lingkungannya sesuai dengan pengelolaan sampah yang baik dan benar di rumah tangga. Mayarakat bisa memberikan sikap dengan baik namun untuk tindakan dalam pengelolaan sampah yang dilakukannya tidak bisa diukur dari tingkat sikapnya, dikarenakan masyarakat hanya memberi tanggapan tanpa diikuti dengan aplikasi terhadap pengelolaan sampah yang baik dan benar.

\section{KESIMPULAN DAN SARAN}

Kepedulian masyarakat terhadap pengelolaan sampah rumah tangga dikategorikan Baik, dengan persentase pengetahuan sebesar $76 \%$, persentase persepsi sebesar $54 \%$, dan persentase sikap sebesar 53\%. Terdapat hubungan signifikan yang cukup dengan nilai signifikan sebesar 0,01 dan berhubungan searah antara pengetahuan dengan pengelolaan sampah rumah tangga dengan angka korelasi sebesar 0,372, sehingga terdapat kecenderungan apabila pengetahuan terus ditingkatkan maka akan meningkatkan pengelolaan sampah rumah tangganya juga. hubungan persepsi dan sikap dengan pengelolaan sampah rumah tangga, yang mana tidak terdapat hubungan yang signifikan dengan nilai 0,817 >0,01 untuk persepsi dan 0,334>0,01 untuk sikap dan terdapat hubungan yang tidak searah antara variabel persepsi dan sikap dengan pengelolaan sampah rumah tangga dengan nilai korelasi negatif, -0,026 untuk nilai korelasi 
persepsi dan -0,106 untuk nilai korelasi sikap, sehingga apabila persepsi dan sikap masyarakat meningkat maka tidak akan meningkatkan pengelolaan sampah rumah tangganya.

Diharapkan untuk masyakat rumah tangga tidak hanya memiliki kepedulian yang baik terhadap pengelolaan sampah namun diikuti dengan tindakan yang baik juga dalam mengelola sampah rumah tangga. Untuk dinas DLHDK3 juga dapat lebih memaksimalkan kinerjanya, tidak hanya memberikan penyuluhan tetapi juga praktek langsung kepada masyarakat mengenai pengelolaan sampah rumah tangga yang baik dan benar, agar masyarakat dapat menerapkan pengelolaan sampah yang baik sesuai aturan $3 \mathrm{M}$ di rumah tangga dan lingkungannya, kemudian juga dapat mendengar keluh kesah dan meningkatkan tindakan masyarakat Kota Banda Aceh terkait pengelolaan sampah rumah tangga sesuai kebijakan yang berlaku di Qanun Aceh No. 5 Tahun 2003 dan di UU Nomor 18 Tahun 2008 Indonesia.

Penelitian selanjutnya diharapkan lebih menekankan untuk meneliti mengenai dampak dari tindakan pengelolaan sampah, melihat variabel-variabel lain yang mungkin dapat diukur tingkatannya baik di rumah tangga atau di lokasi lainnya yang menjadi sumber utama sampah di Kota Banda Aceh.

\section{DAFTAR PUSTAKA}

Abrauw, A. E., Yunus, H. S., \& Giyarsih, S. R. (2011, Mei). Pengetahuan dan Sikap Masyarakat dalam Pengelolaan Sampah Anorganik di Kecamatan Abepura Kota Jayapura. Majalah Geografi Indonesia, XXV(1), 1-14.

Azwar, A. (1990). Pengantar Ilmu Kesehatan Lingkungan. Jakarta: Mutiara Sumber Widya.

Azwar, S. (2010). Sikap Manusia: Teori dan Pengukurannya. Yogyakarta: Pustaka Pelajar.

Bimo, W. (2004). Pengantar Psikologi Umum. Jakarta: Andi.

Bisnawati, \& Maulina. (2012). Pengetahuan Masyarakat Dalam Pengelolaan Sampah. Jurnal Bagian Keilmuan Keperawatan Komunitas.

Darmawan, A. (2014, Juni). Perilaku Masyarakat dalam Mengelola Sampah di Kota Bima Nusa Tenggara Barat. Jurnal Pembangunan Wilayah dan Kota, X(2), 175-186.

Dinas Kebersihan Kota Banda Aceh. (2012). Daur Ulang Sampah Plastik Kota Banda Aceh. Banda Aceh: Dokumen DK3.

Iskani. (2017). Skala Guttman Secara Tradisional (Cross Sectional) Revisi. Jakarta.

Kumar, N., \& Nandini, N. (2013). Community Attitude, Perception, and Willingness towards Solid Waste Management in Bangelore City Karnataka India. International Journal of Environmental Science, IV(1).

Notoatmodjo, S. (2007). Promosi Kesehatan dan Ilmu Perilaku. Jakarta: Rineka Cipta. 
Ottay, R. I., Siagian, I., \& Hutabarat, F. (2015). Gambaran Perilaku Masyarakat Terhadap Pengelolaan Sampah Padat di Kelurahan Malalayang II Kecamatan Malalayang Kota Manado. Jurnal Kedokteran Komunitas dan Tropik, III(1).

Ramadhan, B. (2009). Gambaran Persepsi Keselamatan Berkendara Sepeda Motor pada Siswa/i Sekolah Menengah Atas di Kota Bogor. Jakarta: Skripsi FKM UI.

Simanjuntak, \& H., S. (2007). Pengelolaan Sampah dengan Sistem Komunal di Pemukiman Kota Medan. Bandung: Tesis Magister Program Perencanaan Wilayah dan Kota ITB.

Sudjana. (2005). Metode Stastitika. Jakarta: Tarsito.

Susanto, R., M., L. N., \& Pahroni, R. (2010). Hubungan Pengetahuan Terhadap Pengelolaan Sampah Organik dan Non Organik Pada Masyarakat RW 03 Sumbersari Malang. Jurnal Keperawatan, I(1), 32-38.

Yolarita, E. (2011). Pengelolaan Sampah Dengan Prinsip 3M di Kota Solok. Bandung: Tesis Universitas Padjajaran. 